\title{
Guncangan Harga dan Pangsa Pasar Ekspor Kayu Manis Kabupaten Kerinci
}

\author{
Nurhayani, Rosmeli \\ Prodi Ekonomi Pembangunan Fak. Ekonomi dan Bisnis, Universitas Jambi
}

E-mail:nurhayani@unja.ac.id:rosmeli@unja.ac.id

\begin{abstract}
ABSTRAK
Penelitian ini bertujuan untuk Penelitian ini bertujuan untuk mengetahui dan menganalisis penyebab terjadinya guncangan harga kayu manis, posisi pangsa pasar ekspor kayu manis dan strategi pengembangan kayu manis Kabupaten Kerinci. Data yang digunakan data primer dan pengumpulan data melalui kuisioner dan wawancara. Alat analisis yang digunakan adalah SWOT. Hasil penelitian menunjukkan penyebab terjadinya kenaikan harga kayu manis, karena melonjaknya nilai tukar dolar AS terhadap rupiah, berkurangnya pasokan ke pasar internasional. Turunnya harga kayu manis disebabkan oleh beberapa hal, antara lain rendahnya kualitas kayu manis, kurang maksimalnya pengolahan pascapanen, belum banyak industri yang memberi nilai tambah, kurangnya pendampingan bagi petani, tidak aktifnya kelompok-kelompok tani yang ada. Kabupaten Kerinci sebagai penghasil kayu manis, karena kualitas yang bagus dan faktor kandungan minyak yang tinggi dan menjadi standar produk kayu manis di pasar dunia serta produsen kayu manis terbesar di dunia, dengan menyumbang $43 \%$ dari total produk dunia, hampir semua kayu manis yang di produksi Indonesia berasal dari Kerinci. Hasil analisis QSPM menunjukkan strategi utama adalah mempertahankan kualitas kayu manis.
\end{abstract}

Kata kunci:Pangsa Pasar, Strategi, Kayu Manis

\section{PENDAHULUAN}

Kayu manis terdapat di hampir seluruh wilayah di Indonesia diantaranya PulauSumatera, tersebar di sepanjangpegunungan Bukit Barisan, mulai dari Aceh, Sumatera Utara, Sumatera Barat,Jambi, Bengkulu sampai ke Lampung Pulau Jawa, dan Kalimantan. Namun, sentra produksi kayu manis Indonesia terdapat di Kabupaten Kerinci, Jambi karena merupakan pemasok 80 persen daritotal ekspor kayu manis Indonesia, Kerinci dikenal sebagai penghasil kayu manis (kulit manis) kualitas terbaik di Indonesia, bahkan juga di dunia, karena mengandung kadar minyak mencapai 4\% (Disperindag, 2009).Berbagai permasalahan dalam pengembangan kayu manis di KabupatenKerinci, antara lain (1) terjadinya kecenderungan petani akhirakhirini melakukan panen kayu manis dengan sistem tebang habis sertamelakukan alih fungsi lahan kayu manis menjadi lahan untuk tanaman semusim atau membiarkan lahan petani meninggalkanlahan setelah dipanen menjadi lahan tidur; (2) tidak berkembangnya industriturunan/pengolahan di dalam daerah dan rendahnya kualitas produk yangdihasilkan petani dalam memenuhi permintaan ekspor, padahal komoditastersebut merupakan komoditas unggulan daerah; (3) rendahnya harga komoditasdi tingkat petani (Rustiadi, 2009).

Lima negara pengahasil kulit manis dunia adalah Indonesia sebesar 46\%, China 33,7\%, Vietnam 10,1\%, Srilangka 8,1\% dan Madagaskar 1,1\%. Pada tahun 2013 Ekspor terbesar kayu manis Indonesia adalah Amerika Serikat 45,98\%, Belanda 7,93\%, Thailand 3,77\% dan Brazil 3,43\% (VECO Indonesia dan UNAND, 2015).Kabupaten Kerinci merupakan salah satu wilayah kabupaten terluas dalammelakukan pengembangan kayu manis di Indonesia, pada tahun 2015 dengan areal penanaman seluas 40.962 ha dan nilaiproduksinya mencapai 52.980 ton $(64,92 \%)$ dari total produksi nasional. Angka ini menempatkan KabupatenKerinci sebagai penyumbang utama dari total produksi kayu manis nasional bersama Sumatera Barat. Komoditi kulit sebahagian besar dihasilkan oleh kabupaten Kerinci (Erfit, 2013). Kayumanis yang berasal dari Kerinci ini dikenal memiliki kualitas terbaik di Indonesia (Alimah, 2015). 
Tanaman kayu manis adalah tanaman berupa pohon, tumbuh tegak, dan tinggi tanaman dapat mencapai 15 meter. Batang berkayu, bercabang, warna hijau kecokelatan, daun tunggal, berbentuk lanset, ujung dan pangkal meruncing, tepi rata, saatmasih muda berwarna merah tua atau hijau ungu, daun tua berwarna hijau, bungamajemuk malai, muncul dari ketiak daun, berambut halus, mahkota berwarnakuning. Buah buni, warna hijau waktu muda dan hitam setelah tua. Biji kecil,bentuk bulat telur. Kulit batang mengandung dammar, lender, dan minyak asiri yang mudah larut (Syukur dan Hermani, 2001). Suwarto (2014) Tanaman kayu manis menghendaki iklim yang lembab dan banyak hujan sepanjang tahun, serta tidak ada musim kering yang panjang. Suhu rata-rata untuk pertumbuhan kayu manis berkisar $18-27^{\circ} \mathrm{C}$. Akan tetapi suhu rata-rata optimm untuk budidaya kayu manis adalah $25^{\circ} \mathrm{C}$. Banyak sekali manfaat kayu manis dapat dijadikan bumbu masakan daging danikan, dan sebagai campuran dalam minuman(teh, kopi, dan kakao). Secara imperis kulitkering kayu manis yang direndam dalam air tehdan diminum dapat menurunkan kadarkolesterol tubuh dan mengencerkan darahsehingga baik untuk penderita stroke(Ferry, 2013).

Menurut Susila (2004), subsektor perkebunan merupakan salah satu subsektoryang mengalami pertumbuhan paling konsisten, baik ditinjau dari areal maupunproduksi. Secara keseluruhan, areal perkebunan meningkat dengan laju $2.6 \%$ pertahun pada periode tahun 2000-2003, dengan total areal pada tahun 2003 mencapai16.3 juta. Dari beberapa komoditas perkebunan yang penting di Indonesia (karet,kelapa sawit, kelapa, kopi, kakao, teh, dan tebu), kelapa sawit, karet dan kakaotumbuh lebih pesat dibandingkan dengan tanaman perkebunan lainnya dengan lajupertumbuhan diatas $5 \%$ per tahun.

Dumairy (2000) Tanaman perkebunan merupakan pendukung utama sektor pertanian dalam menghasilkan devisa. Ekspor komoditas pertanian kita yang utama adalah hasil-hasil perkebunan. Hasil-hasil perkebunan yang selama ini telah menjadi komoditas ekspor konvensional terdiri atas karet, kelapa sawit, teh, kopi dan tembakau. Masih ada jenis tanaman yang perkebunan yang diekspor, namun porsinya relaitf kecil. Penghasil devisa utama dari subsektor perkebunan adalah karet dan sawit.

\section{METODEPENELITIAN}

Penelitian ini menggunakan data primer dan data sekunder. Data primer diperoleh dari wawancara dengan petani kayu manis, tengkulak (toke)dan Dinas Pertanian. Lokasi penelitian dilakukan di Kabupaten Kerinci, Provinsi Jambi. Pengambilan data sampel petani, tengkulak (toke) dan pihak yang berkaitan dilakukan selama dua bulan yaitu sejak Juli - Agustus 2018. Penentuan sampel petani dalam penelitian ini dilakukan dengan sengaja (purposive). Jumlah responden petani terdiri dari 2 pengambil kebijakan dan 1 orang tengkulak (toke)di Kabupaten Kerinci.

Metode analisis data dengan metode deskriptif dan kuantitatif. Metode deskriptif adalah merupakan suatu metode penelitian yang bertujuan untuk menggambarkan secara tepat sifat-sifat suatu keadaan atau gejala-gejala individu atau kelompok tertentu dalam masyarakat (Amir, dkk, 2009).Metode deskriptif ini digunakan untuk menganalisis tujuan yang pertama dan kedua yaitu tentang yang menyebabkan terjadinya guncangan harga kayu manis dan posisi pangsa pasar ekspor kayu manis Kabupaten Kerinci.Metode kuantitatifdigunakan untuk menganalisis tujuan ke tiga yaitu strategi pengembangan kayu manis Kabupaten Kerinci (SWOT/Strenght Weaknesses Opportunities Threats). Matriks SWOT dapat menggambarkan secara jelas bagaimana peluang dan ancaman dari faktor eksternal yang dapat disesuaikan dengan kekuatan dan kelemahan yang dimiliki (Rangkuti, 2015).

Metode ini digunakan untuk mengetahui metode strategi pengembangan melalui analisis SWOT dengan cara menganalisis faktor-faktor eksternal (peluang dan ancaman) dan faktor-faktor internal (kekuatan dan kelemahan) dengan matriks EFE dan IFE. Matriks 
External Factor Evaluation (EFE) digunakan untuk menganalisis faktor-faktor yang berupa peluang dan ancaman yang dihadapi. Matriks Internal Factor Evaluation (IFE) digunakan untukmenganalisis faktor-faktor yang berupa kekuatan dan kelemahan yang dimiliki.Tahap berikutnya adalah Pencocokan (Matrik IE dan Matrik SWOT). Pada matrik IE sumbu X terdapat tiga skor yang menentukan posisi dari suatu perusahaan yaitu skor 1,00-1,99 menunjukkan bahwa perusahaan berada pada posisi internal yang lemah, skor 2,00-2,99 menunjukkan bahwa perusahaan berada pada posisi internal rata-rata, dan skor 3,00-4,00 menunjukkan bahwa perusahaan berada pada posisi internal yang kuat. Penjelasan yang sama juga pada sumbu $\mathrm{Y}$ terdapat tiga skor yang menentukan posisi suatu perusahaan yaitu skor 1,00-1,99 menunjukkan bahwa perusahaan memiliki posisi eksternal yang rendah, skor 2,002,99 menunjukkan bahwa perusahaan memiliki posisi eksternal rata-rata, dan skor 3,00-4,00 menunjukkan bahwa perusahaan memiliki posisi eksternal yang tinggi.

Tahap yang terakhir adalah tahap penetapan keputusan yaitu menggunakan matrik QSPM (Quantitative Strategic Planning Matrrix). Analisis ini memungkinkan ahli strategi untuk mengevaluasi alternatif stategi secara objektif dengan penilain intuitif yang baik berdasarkan pada faktor-faktor kritis untuk lingkungan internal dan eksternal yang telah diketahui.

Alimah (2015) melakukan penelitian tentang study pengusahaan kayu manis Di Hulu Sungai Selatan, bertujuan penelitian untuk mengetahui pemanfaatan dan pengusahaan kayu manisyang dilakukan oleh masyarakat di Kecamatan Loksado, Kabupaten Hulu Sungai Selatan, KalimantanSelatan. Penelitian ini dilakukan dengan cara mengumpulkan data sekunder Hasil penelitian menunjukkan bahwa pengusahaan kayu manis di Loksado, Kab. Hulu Sungai Selatan masihterbatas pada pengusahaan bagian kulit dari pohon kayu manisnya saja. Kegiatan yang dilakukan meliputiproduksi, penjemuran kulit kayu manis, dan distribusi produk dari kulit kayu manis baik itu dalam bentukgulungan (mentah) maupun sirup.Iskandar (2012) volume ekspor kayu manis Indonesia ke Amerika Serikat dipengaruhi oleh perubahan harga riil ekspor kayu manis, harga kayu manis domestik dipengaruhi oleh harga riil pada eksportir kayu manis dalam satuan dolar, dan harga kayu manis asli domestik. Volume ekspor kayu manis Indonesia ke Amerika Serikat dipengaruhiharga. Menggala (2018) pemerintah daerah dan pusat dapat membantu petani agar dapat menghasilkan produktivitas yang lebih tinggi dan sesuai dengan standar operasional. Pemerintah Indonesia juga harus membimbing petani kecil yang terkait dengan permintaan pasar internasional untuk sertifikasi produk, dan standar kualitas mempersulit petani kecil untuk memenuhi permintaan tersebut.

\section{HASIL PENELITIAN DAN PEMBAHASAN}

\section{Penyebabkan Terjadinya Guncangan Harga Kayu Manis Di Kabupaten Kerinci}

Tahun 1990 sampai tahun 2007 harga kayu manis berkisar Rp. 2.000/Kg sampai dengan Rp. $2.500 / \mathrm{Kg}$. Hal ini mengakibatkan banyak petani yang tidak memanen kayu manis atau bahkan banyak yang mendiversifikasi lahan mereka dengan tanaman semusim untuk memenuhi kebutuhan hidup sehari-hari. Namun, penjualan di tingkat pedagang tengkulak dan eksportir tetap tinggi, bahkan mencapai lima kali lipat.Rendahnya harga kayu manis disebabkan oleh beberapa hal antara lain, petani tidak dapat mempengaruhi harga, berkurangnya permintaan pasar internasional (permintaan kulit kayu manis biasanya meningkat saat musim dingin di Eropa dan Amerika Serikat), curah hujan yang tinggi juga menjadi faktor rendahnya harga kayu manis, karena rata-rata kulit manis tersebut harus dijemur ulang. Petani banyak yang beralih ke tanaman yang tidak membutuhkan waktu yang cukup lama untuk dipanen, misalnya kopi dan tanaman palawija atau tanaman lainnya. 
Namun demikian ada juga sebagian petani yang tetap membiarkan tanaman kayu manisnya, karena masih memiliki lahan yang dapat ditanami.

Harga kayu manis mulai naik pada tahun 2013 dengan kualitas bagus yaitu Rp. 17.000,-/Kg. Selain naiknya kurs dolar Amerika Serikat terhadap rupiah, harga diduga naik karena pasokan kayu manis berkurang akibat harga rendah, sementara permintaan pasar meningkat. Pada tahun 2016harga kayu manis mencapai Rp. 24.000,-/Kg. kenaikan harga terus terjadi pada tahun 2017 mencapai Rp.32.000,-/Kg., bahkan pertengahan tahun 2018 harga kayu manis mencapai harga Rp.40.000,-/Kg. Kenaikan harga kayu manis membuat petani kembali menanam kayu manis dan memberikan harapan agar dapat lebih sejahtera dari hasil kayu manis.Kenaikan harga kayu manis, disebabkan oleh beberapa faktor, antara lain, Karena melonjaknya nilai tukar dolar AS terhadap rupiah dan Berkurangnya pasokan ke pasar internasional, permintaan pasar dunia terus meningkat juga menjadi pemicu niaknya harga kayu manis. Di Amerika Serikat saja membutuhkan 25.000 ton cassiavera per tahun, belum lagi Eropa, Timur Tengah, dan Asia.

Petani menghadapi berbagai masalah dalam berkebun kayu manis. Awal milenium baru merupakan titik balik bagi petani kayu manis. Harga kayu manis terjun bebas, dari lebih dari Rp. 10.000/kg menjadi Rp. 1.500-2.000/kg. Padahal petani harus menunggu lebih dari 10 tahun untuk bisa memanen kayu manisnya. Bahkan pernah terjadi penebangan besar-besaran sebagai akibat kekecewaan petani terhadap harga yang sangat rendah.Turunnya harga kayu manis disebabkan oleh beberapa hal, Rendahnya kualitas kayu manis, Kurang maksimalnya pengolahan pascapanen. Belum banyak industri yang memberi nilai tambah, kurangnya pendampingan bagi petani, dan tidak aktifnya kelompok-kelompok tani. Kelompok tani juga harus diperkuat untuk mengurangi ketergantungan petani dari para tengkulak dan biaya-biaya tata niaga dapat ditekan, sehingga para petani bisa menikmati hasil dari berkebun kayu manis.

\section{Posisi Pangsa Pasar Ekspor Kayu Manis Kabupaten Kerinci}

Kayu manis yang termasuk dalam keluarga Lauraceae adalah salah satu dari banyak pohon yang memiliki nilai ekonomi dari kulit kayunya. Terdapat lebih dari 50 jenis kayu manis yang tersebar luas dari Cina sampai Asia Tenggara. Kayu manis asal Indonesia ini merupakan spesies Cinamomum burmanii dan dikenal sebagai Padang Cinnamon, Koerintji Cinnamon atau Casiavera. Di Indonesia, kayu manis pertama kali ditanam pada masa kolonial Belanda di Jawa Barat. Namun karena kualitas yang dihasilkan kurang baik, penanaman dipindahkan ke dataran tinggi diantaranya Kabupaten Kerinci di Propinsi Jambi.. Total luas areal penanaman kayu manis di Kab. Kerinci mencapai sekitar 30.000 hektar. Sementara di seluruh Provinsi Sumetera Barat hanya sekitar 7.000 hektar. Demikian terkenalnya Kab. Kerinci sebagai penghasil kayu manis, sampai-sampai nama "Kerinci" pun menjadi standar produk kayu manis di pasar dunia. Pada tahun 2014 Indonesia sebagai produsen kayu manis terbesar di dunia, dengan menyumbang $43 \%$ dari total produk dunia, hampir semua kayu manis yang di produksi Indonesia berasal dari Kerinci yang populer karena kualitas yang bagus dan faktor kandungan minyak yang tinggi.

Produksi kayu manis petani di Kerinci terbilang luar biasa, setidaknya ada 100 ton kulit manis yang dijual keluar daerah. Kayu manis dijual ke Padang, di Padang ada tujuh perusahaan besar yang menampung kulit manis. Kulit manis Kerinci sampai di Padang diolah kembali menjadi barang setengah jadi. Setelah itu dikirim ke Amerika Serikat, selain sebagai bahan campuran kue, kulit manis di Amerika dijadikan minuman, terutama saat musim dingin. kulit manis yang dikirim eksportir ke Eropa tidak pernah memenuhi kebutuhan pasar sehingga kulit manis ini masih punya potensi besar bagi petani. 


\section{Strategi Pengembangan Kayu Manis Kabupaten Kerinci}

\section{Faktor Internal Pengembangan Kayu Manis}

\section{- Strenghts (Kekuatan)}

Kualitas kayu manis yang bagus. Indonesia dikenal sebagai penghasil komoditi unggulan berupa kayu manis (cinnamon) terbesar di dunia dan sekaligus memiliki kualitas prima dibandingkan negara produsen lainnya. Saat ini Indonesia masih menjadi eksportir utama bagi komoditi satu ini dengan pangsa pasar 35\%.Potensi lahan yang luas. Kabupaten Kerinci masih banyak memiliki lahan yang dapat di garap yaitu sebanyak 40.000 ha. lahan ini dapat di manfaatkan untuk bercocok tanam bagi masyarakat di sekitarnya. Lahan ini dapat di tanami kayu manis yang diselingi dengan penenaman palawija. Banyaknya manfaat dari kayu manis. Banyak sekali manfaat kayu manis diantaranya, minyak atsiri dari kayu manis mempunyai daya bunuh terhadap mikroorganisme, membangkitkan selera atau menguatkan lambung juga memiliki efek untuk mengeluarkan angin. Selain itu minyaknya dapat digunakan dalam industri sebagai obat kumur dan pasta, penyegar bau sabun, deterjen, lotion parfum dan cream. Dalam pengolahan bahan makanan dan minuman minyak kayu manis di gunakan sebagai pewangi atau peningkat cita rasa, diantaranya untuk minuman keras, minuman ringan, agar-agar, kue, kembang gula, bumbu gulai dan sup.Luasnya pangsa pasar. Pangsa pasar kayu manis selain di dalam negeri juga di Luar Negeri. Amerika Serikat masih menjadi importir terbesar, disusul India, Uni Emirat Arab, Meksiko, Belanda, negara-negara Timur Tengah, Singapura, Korea, Brasil, dan Jepang. Ekspor kayu manis Indonesia sebagian besar dalam bentuk gulungan dan broken, sedangkan dalam bentuk powder masih sangat sedikit.Jarak lokasi penanaman dengan distribusi penjualan kulit manis strategisLokasi penanaman kayu manis rata-rata masih dapat di lalui kendaraan roda empat atau roda dua, walaupun masih banyak jalan yang rusak. Setelah melalui proses penen dan penjemuran, kayu manis dapat langsung dijual ke tengkulak atau di jual ke Sumatra Barat.

Weaknesses (kelemahan)

Rendahnya pengetahuan masyarakat tentang produk turunan kayu manis.Masyarakat Kerinci belum banyak yang mampu memberi nilai tambah dari kayu manis (cassiavera),karena rendahnya pengetahuan atauwawasan tentang produk turunan sehingga petani hanya mengekspor bahan mentah. Ekspor kayu manis sebagian besar dalam bentuk gulungan dan broken, sedangkan dalam bentuk powder masih sangat sedikit. Kurangnya kegiatan penyuluhan dalam pengembangan kayu manisPenyuluhan tentang kayu manis relatif masih kurang, masyarakat menanam kayu manis hanya berdasarkan pengalaman dan informasi sesama petani kayu manis. Peran pemerintah belum maksimal terhadap produk kayu manis.Peran pemerintah sangat penting dalam pengembangan produk olahan kayu manis, namun peran pemerintah belum maksimal, sehingga masyarakat atau petani cenderung menjual kayu manis dalam bentuk mentah tampa ada nilai tambah produk.Pemerintah hendaknya terus memfasilitasi sehingga komoditas unggulan tetap terjaga dan bagi masyarakat dapat meningkatkan pendapatan dan kesejahteraan.

\section{Faktor Eksternal Pengembangan Kayu Manis}

\section{Opportunities (peluang)}

Meningkatnya peluang produk turunan dari kayu manis. Produk turunan kayu manis sebenarnya banyak sekali, bisa dibuat dalam bentuk bubuk dan minyak. Pengolahan kayu manis agar menjadi produk turunan akan dapat menambah nilai jual produk dapat menjadi lebih tinggi dari pada menjual produk mentah yang harganya jauh lebih rendah.Memiliki pangsa pasar luas dalam produk olahan kayu manis. Berbagai manfaat dari kayu manis hingga membuat kayu manis banyak dibutuhkan, baik mentah atau sudah dalam bentuk produk, 
misalnya minyak atsiri, bukuk kayu manis dan sirup. Banyaknya manfaat kayu manis sehingga pangsa pasar menjadi luas. Meningkatnya devisa negara. Meningkatanya permintaan ekspor kayu manis dari tahun ke tahun sehingga mampu meningkatkan devisa dan nilai tambah yang besar bagi petani dan pengekspor. Menyesuaikan dengan perubahan iklim. Tanaman Cassiaveramenghendaki iklim yang lembab dan banyak hujan sepanjang tahun, serta tidak ada musim kering yang panjang. Suhu rata-rata untuk pertumbuhan Cassiaveraberkisar $18-27^{\circ} \mathrm{C}$. Pada curah hujan rendah pertumbuhan menjadi terhambat dan produksi menjadi lebih sedikit. Tanah yang paling cocok untuk tanaman Cassiavera adalah tanah yang subur, gembur, agak berpasir, dan kaya akan bahan organik. Kondisi ini sangat cocok dengan iklim di daerah Kabepaten Kerinci.Komoditi ekspor unggulan Di Indonesia. Perlu adanya perbaikan dan penanaman kembali tanaman yang sudah rusak agar di tahuntahun mendatang produksi komoditas ekspor akan semakin meningkat. Karena ke depan, permintaan akan semakin meningkat, jika kita tidak mampu memenuhinya maka akan kehilangan pasar.

- Threats (ancaman)

Meningkatnya perkembangan kayu manis diberbagai negaraSelain Indonesia kayu manis dihasilkan juga oleh Sri Lanka, Tiongkok, Vietnam, dan India, bahkan Hongkong bisa mengekspor olahan dengan harga tinggi. Dibeberapa negara panen kayu manis tidak dilakukan dengan cara tebang habis, tapi dengan cara mengupas beberapa sisi dan beberapa waktu sisi yang dikupas akan tumbuh kulit yang baru kemudian petani dapat mengupas sisi yang lain. Dengan metode ini panen kayu mnis tidak perlu menunggu waktu yang cukup lama.Meningkatnya promosi produk-produk olahan kayu manis di negara lainDi negaranegara lain promosi produk olahan kayu manis semakin gencar dilakukan. Sebagian besar tidak menjual kayu manis dalam bentuk mentah, namun sudah dalam bentuk produk jadi atau setengah jadi.Menguntungkan pihak tengkulakKendali tengkulak dalam pasaran harga kayu manis memang tidak bisa dihindari, karena sebagian petani melakukan pinjaman kepada tengkulak sebelum panen dilakukan sebagai biaya panen atau untuk keperluan keluaga seharihari. Rendahnya harga di tingkat petani ini disebabkan karena rendahnya mutu produk yang dihasilkan. Rendahnya mutu disebabkan oleh tingginya kadar air, banyaknya campuran benda asing. Di tingkat petani, penurunan mutu produk disebabkan karena pascapanen yang masih sangat sederhana, pemanenan sebelum waktunya, peralatan panen yang tidak steril (korosi), serta cara pengeringan yang kurang baik. Rendahnya mutu ini mengakibatkan rendahnya tingkat harga kayu manis.Berdirinya pabrik kayu manis di negara lain dengan menggunakan teknologi yang lebih tinggi. Adanya pabrik pengolahan kayu manis dengan teknologi tinggi di negara penghasil kayu manis merupakan ancaman yang cukup besar, bagi perkembangan kayu manis Kerinci.Petani menjual kayu manis dalam bentuk kulit baik dalam keadaan basah maupun kering, dengan kata lain dapat dikatakan bahwa petani hanya mampu menjual kayu manis dalam bentuk produk primer, belum melakukan pengolahan. Terbatasnya kemampuan petani dalam pengembangan produk olahan kayu manis mengakibatkan petani hanya mendapatkan keuntungan yang kecil dari hasil penjualan.

\section{Matrik Internal Factor Evaluation (IFE)}

Berdasarakan perhitungan diperoleh total skor dari matrik IFE sebesar 2,70. Nilai ini menunjukkan bahwa kayu manis memiliki posisi internal yang kuat karena nilai skor di atas 2,5. Kekuatan utama dari kayu manis adalah luasnya pangsa pasar $(0,51)$ dan kekuatanlain yang dimiliki berdasarkan nilai skor adalah Banyaknya manfaat dari kayu manis $(0,42)$, Kualitas kayu manis yang bagus $(0,39)$, potensi lahan yang luas $(0,35)$, dan Jarak lokasi penanaman dengan distribusi penjualan kulit manis strategis $(0,24)$. Kelemahan utama kayu manisadalah Rendahnya harga kayu manis tengkulak $(0,10)$ dan kelemahan lainnya yang 
dimiliki berdasarkan nilai skor adalahRendahnya pengetahuan masyarakat tentang produk turunan kayu manis $(0,16)$, Peran pemerintah belum maksimal terhadap produk kayu manis $(0,21)$, Peran pemerintah belum maksimal terhadap produk kayu manis $(0,21)$.

\section{Matrik Eksternal Factor Evaluation (EFE)}

Total skor dari matrik EFE sebesar 2,27. Nilai ini menunjukkan bahwa kayu manis dapat dikatakan mampu menarik keuntungan dari peluang eksternal dan menghindari ancaman yang menghadang.Peluang utama kayu manis adalah Memiliki pangsa pasar luas dalam produk olahan kayu manis $(0,47)$ dan peluang lainnya yang diperoleh adalah Meningkatnya peluang produk turunan dari kayu manis $(0,35)$, Memiliki pangsa pasar luas dalam produk olahan kayu manis $(0,27)$, Meningkatnya devisa negara $(0,245)$ dan Menyesuaikan dengan perubahan iklim (0,241). Ancaman utama kayu manis adalah Meningkatnya perkembangan kayu manis diberbagai negara $(0,21)$ dan ancaman lainnya yang diperoleh berdasarkan nilai skor adalah Meningkatnya promosi produk-produk olahan kayu manis di negara lain $(0,20)$ Menguntungkan pihak tengkulak $(0,13)$, Kemungkinan berdirinya pabrik kayu manis di negara lain dengan menggunakan teknologi yang lebih tinggi $(0,13)$.

\section{Tahap Pencocokan (Matrik IE dan Matrik SWOT)}

Matrik IE merupakan gabungan dari hasil matrik IFE dan matrik EFE kemudian dipetakan sehingga dapat diketahui posisi dari koperasi. Matrik IE mempermudah dalam memberikan alternatif bagi koperasi dalam menghadapi persaingan. Nilai matrik IFE dan matrik EFE didapatkan dari total skor masingmasing matrik dimana pada matrik IFE didapatkan nilai total skor sebesar 2,70 dan matrik EFE diperoleh nilai total skor sebesar 2,27 yang apabila nilai tersebut dipetakan ke dalam matrik IE berada pada kuadran V. Peta matrik IE dapat dilihat pada Gambar 1.1.Terlihat pada Gambar 5.1 bahwa pengembangan kayu manis terletak padaposisi Holdand Maintain (pertahankan dan pelihara). Holdand maintain yang dilakukan dapat dilihat dari faktor-faktor kekuatan dan peluang yang dimiliki. Faktor kekuatan merupakan faktor yang harus dipertahankan sedangkan faktor peluang merupakan faktor yang harus dipelihara. Berdasarkan faktor internal dan eksternal yang didapatkan untuk harus mempertahankan kualitas kayu manis untuk mempertahankan keunggulan kayu manis sebagai komoditi ekspor unggulan Indonesia karena tingginya permintaan pasar untuk kayu manis.

Tahap terakhir dalam merumuskan strategi adalah tahap keputusan dengan menggunakan matrik Quantitative Strategic Planning Matrix (QSPM) yang bertujuan untuk mengevaluasi alternatif strategi yang paling memungkinkan untuk dijalankan terlebih dahulu, beberapa strategi alternatif yang telah dirumuskan adalah1). Mempertahankan kualitas kayu manis, 2) Pemanfaatan fasilitas dari lembaga keuangan, 3)Pengembangan sumberdaya dan produk turunan dari kayu manis, 4) Memperluas jaringan ekspor kayu manis, 5) Membuka unit usaha untuk produk turunan kayu manis. Berdasarkan perhitungan QSPM diperoleh nilai STAS tertinggi adalah mempertahankan kualitas kayu manis sebesar 6,29, sedangkan strategi alternatif lainnya adalah Pengembangan sumber daya dan produk turunan dari kayu manis. (nilai STAS5,56), membuka unit usaha untuk produk turunan kayu manis (nilai STAS5,48), memperluas jaringan ekspor kayu manis. (niali STAS5,41), dan pemanfaatan fasilitas dari lembaga keuangan yang ada (nilai STAS 4,95). Terpilihnya alternatif strategi utamaya itu mempertahankan kualitas kayu manis merupakan strategi yang tepat untuk pengembangan kayu manis, karena dengan mempertahankan kualitas kayu manis, maka harga akan tetap tinggi dan memungkinkan meningkatnya permintaan pasar. 


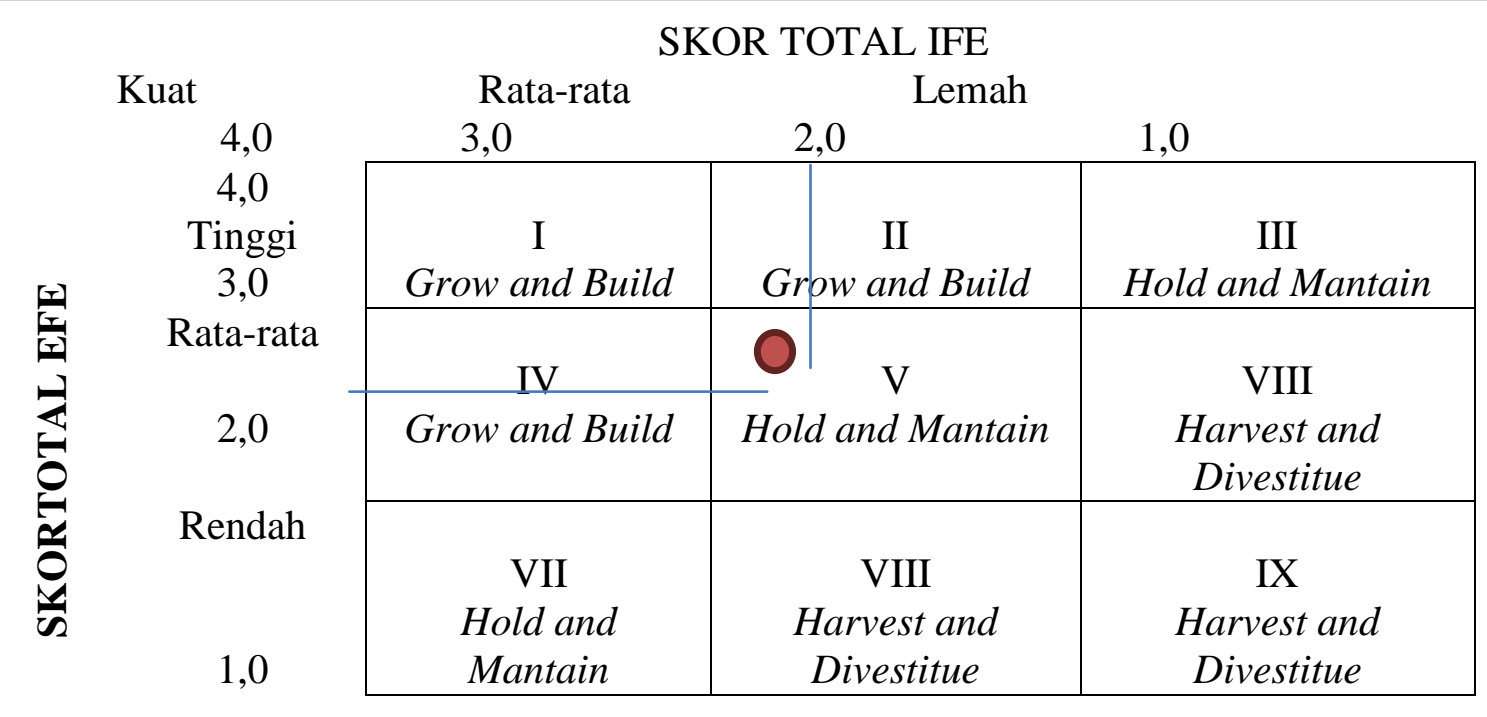

Gambar1.1.HasilAnalisis MatrikIE

\section{KESIMPULAN DAN SARAN}

\subsection{Kesimpulan}

Penyebab terjadinya kenaikan harga kayu manis, karena melonjaknya nilai tukar dolar AS terhadap rupiah, berkurangnya pasokan ke pasar internasional. Turunnya harga kayu manis disebabkan oleh beberapa hal, antara lain rendahnya kualitas kayu manis, kurang maksimalnya pengolahan pascapanen, belum banyak industri yang memberi nilai tambah, kurangnya pendampingan bagi petani, tidak aktifnya kelompok-kelompok tani yang ada.Kabupaten Kerinci sebagai penghasil kayu manis, karena kualitas yang bagus dan faktor kandungan minyak yang tinggi, sampai-sampai nama "Kerinci" pun menjadi standar produk kayu manis di pasar dunia dan sebagai produsen kayu manis terbesar di dunia, dengan menyumbang $43 \%$ dari total produk dunia, hampir semua kayu manis yang di produksi Indonesia berasal dari Kerinci. Proses keputusan alternatif strategi terbaik dilakukan melalui analisis QSPM. Hasil analisis QSPM menunjukkan strategi utama adalahmempertahankan kualitas kayu manis.

\section{a. Saran}

Kualitas produksi harus tetap dijaga, mulai dari penanaman, pemeliharaan sampai saat panen serta pascapanen sehingga akan memenuhi standar terutama untuk ekspor. Harus mengembangkan produk turunan dari kayu manis sehingga akan menambah nilai produk dan diharapkan pemeritah dapat memberikan pelatihan atau penyuluhan agar petani memahami pengolahan kayu manis yang baik.Petani, kelompok-kelompok tani atau pemerintah harus mencari pangsa pasar yang lain dan memanfaatkan lembaga keungan yang ada, sehingga harga kayu manis tidak dikendalikan oleh toke.

\section{b. Ucapan Terimakasih.}

Pada kesempatan yang berbahagia ini penulis mengucapkan terima kasih kepada:

1. Universitas Jambi yang telah memberikan dana untuk pelaksanaan penelitianini.

2. Jurnal Sosio Humaniora Universitas Jambi yang telah berkenan menerbitkan artikel penulis. 


\section{DAFTAR PUSTAKA}

Alimah, D. (2015). Study Pengusahaan Kayu Manis Di Hulu Sungai Selatan. Balai Penelitian Kehutanan Banjarbaru. Galam Volume 1 Nomor 1.

Amri, A, Junaidi, yulmardi. (2009). Metodelogi Penelitian Ekonomi dan Penerapannya. IPB PRESS. Bogor.

Dumairy. (2000). Perekonomian Indonesia, Penerbit Erlangga, Jakarta

Erfit. (2013). Studi Tentang kinerja Sektor Pertanian Provinsi Jambi Tahun 2005 - 2009. Jurnal Paradigma Ekonomika. Vol. 1. No.7 . April 2013. Hal. 25 - 32.

Ferry, Y. (2013). Prospek Pengembangan Kayu Manis Di Indonesia. SIRINOV, Vol 1, No 1, April. Hal : $11-20$.

Iskandar, S, dkk. (2102).Analysis of Determinant Factors Influencing Cinnamon Export and Prices in Indonesia"PROCEEDING The 13th Malaysia Indonesia Conference on Economics, Management and Accounting (MIICEMA)

Laporan Riset Rantai Pemasaran Kayu Manis, (2015). VECO Indonesia dan Fakultas Pertanian Universitas Andalas Padang.

Menggala. (2018). Improving Cinnamomum Burmannii Blume Value Chains for Farmer Livelihood in Kerinci, Indonesia. European Journal of Medicine and Natural Sciences January-April 2018 Volume 2. Issue 1. Hal. 22 - 42

Rangkuti. F (2015). Analisis SWOT Teknik Pembeda Kasus Bisnis . Jakarta: PT Gramedia Pustaka Utama.

Rustiadi, Askar, J, dkk . (2009). Dampak Pengembangan Komoditas Kayu Manis Rakyat Terhadap Perekonomian Wilayah: Kabupaten Kerinci, Provinsi Jambi. Laporan hasil penelitian forum pasca sarjana.

Susila W, Setiawan I,D. 2007. Peranan Industri Perkebunan Dalam Pertumbuhan Ekonomi Dan Pemerataaan: Pendekatan Sistem Neraca Sosial Ekonomi. Jurnal Agro Ekonomi Volume 25 No. 2 : 125-147.

Syukur, C dan Hermani., (2001), Budidaya Tanaman Obat Komersial. Penerbit Penebar Swadaya, Jakarta. 